Risandi, F.H. • M. Ariyanti · M.A. Soleh

\title{
Respons pertumbuhan tanaman kelapa kopyor (Cocos nucifera L.) belum menghasilkan terhadap pemberian pupuk anorganik yang dikombinasikan dengan pupuk organik cair
}

Sari. Kelapa kopyor merupakan salah satu plasma nutfah yang ada di Indonesia dan potensial untuk dikembangkan. Upaya peningkatan produktivitas kelapa kopyor dapat melalui pemupukan, yaitu dengan pemberian pupuk anorganik dan pupuk organik cair. Penelitian ini bertujuan untuk mengetahui pemupukan yang tepat untuk tanaman kelapa kopyor belum menghasilkan dengan kombinasi pupuk anorganik dan pupuk organik cair. Penelitian ini dilaksanakan di Lahan PT. Mekar Unggul Sari (Taman Buah Mekarsari), Cileungsi, Bogor, Jawa Barat, pada bulan Juli sampai dengan Desember 2018. Penelitian ini menggunakan Rancangan Acak Kelompok (RAK), yang terdiri dari 16 perlakuan dan masing-masing perlakuan terdiri dari 2 tanaman dan diulang sebanyak 2 kali. Hasil penelitian menunjukan bahwa kombinasi dosis $50 \%$ pupuk anorganik dengan $25 \%$ dosis pupuk organik cair dari dosis anjuran cenderung berpengaruh baik pada parameter pertambahan tinggi tanaman, lilit batang, dan jumlah daun, sementara kombinasi dosis $75 \%$ pupuk anorganik dan $125 \%$ dosis pupuk organik cair cenderung meningkatkan rata-rata luas daun.

Kata kunci : Pupuk anorganik $\cdot$ Pupuk organik cair $\cdot$ Kelapa kopyor

\section{The growth response of immature kopyor coconut plant (Cocos nucifera L.) to application inorganic fertilizer of combination and liquid organic fertilizer}

\begin{abstract}
Kopyor coconut is one of the germplasm from Indonesia and potential to be developed. Efforts to increase the productivity of kopyor coconut can be through fertilization, by providing inorganic fertilizers and liquid organic fertilizers. This study aimed to understand the right fertilization for young kopyor coconut plants that applied by combination of of inorganic fertilizer and liquid organic fertilizer. This research was conducted at the PT. Mekar Unggul Sari (Mekarsari Fruit Garden), Cileungsi, Bogor, West Java, from July to December 2018. It used a Randomized Block Design (RBD), that consisted of 16 treatments and each treatment consisted of 2 plants and repeated 2 times. The results showed that the combination of $50 \%$ dosage of inorganic fertilizer with $25 \%$ dosage of liquid organic fertilizer had a trendto give better effect on plant height, stem diameter, and leaf number, while $75 \%$ dosage of inorganic fertilizer with $125 \%$ dosage of liquid organic fertilizer tend to gave better effect on leaf area.
\end{abstract}

Keywords : Inorganic fertilizer $\cdot$ Liquid organic fertilizer $\cdot$ Kopyor coconut

Diterima : 12 September 2019, Disetujui : 26 Maret 2020, Dipublikasikan : 31 Maret 2020 doi: https://doi.org/10.24198/kultivasi.v19i1.23607

\footnotetext{
Risandi, F.H. · M. Ariyanti · M.A. Soleh

Departemen Budidaya Pertanian Fakultas Pertanian Universitas Padjadjaran

Korespondensi: fatwahrr@gmail.com
} 


\section{Pendahuluan}

Kelapa kopyor merupakan salah satu plasma nutfah asal Indonesia dan memiliki nilai ekonomi yang tinggi. Jumlah tanaman dan produktivitas kelapa kopyor masih sangat rendah sehingga berpengaruh terhadap harga jual yang relatif mahal,

Tanaman kelapa kopyor tersebar di berbagai daerah di Indonesia. Salah satu daerah sentra produksi kelapa kopyor yaitu Kabupaten Pati, Jawa Tengah, dengan luas areal pertanaman 378.09 ha. Keunggulan kelapa kopyor asal Pati yaitu cepat berbuah dengan umur 3-4 tahun dan dikategorikan jenis kelapa genjah dengan persentase menghasilkan mencapai $50 \%$ buah kopyor per tandan dan merupakan hasil yang tinggi untuk jenis kelapa kopyor (Bursatianyo, 2015).

Peningkatan produktivitas tanaman kelapa kopyor juga dapat ditunjang dengan hal lain seperti pemupukan. Pemupukan pada tanaman kelapa kopyor dapat menggunakan pupuk padat maupun cair. Pemupukan ini sangat diperlukan untuk pertumbuhan vegetatif dan generatif yang normal, agar kebutuhan hara makro terpenuhi dan menghasilkan produksi buah kelapa kopyor yang optimal (Hariokusumo, 2016).

Pemupukan pada tanaman kelapa kopyor dapat dilakukan dengan pemberian pupuk anorganik seperti N, P, dan K. Pupuk N, P, dan $\mathrm{K}$ merupakan unsur-unsur hara makro yang diberikan pada tanaman kelapa kopyor yang dapat membantu dalam pemenuhan unsur hara untuk pertumbuhan dan produksi kelapa kopyor (Hariokusumo, 2016). Unsur hara makro berperan dalam peningkatan produktivitas tanaman kelapa (Nelliat et al., 1974 dalam Hariokusumo, 2016).

Unsur nitrogen yang diberikan pada tanaman kelapa dapat meningkatkan tinggi tanaman, jumlah daun, tandan buah, dan bunga betina. Unsur fosfor berperan dalam pertumbuhan tanaman. Luas daun, warna hijau daun, dan ukuran serta berat buah dapat diperbaiki dengan pemberian kalium. Unsur kalium juga dapat mengatur penggunaan air pada tanaman, karena dapat memanfaatkan persediaan air yang terbatas (Menon dan Pandalai, 1958 dalam (Hariokusumo 2016). Pemupukan yang dapat diberikan pada tanaman kelapa selain pupuk anorganik dapat juga dilakukan pemupukan dengan pupuk organik.
Pemupukan menggunakan pupuk anorganik secara terus-menerus memiliki dampak negatif bagi keseimbangan mikroorganisme di dalam tanah, dapat menurunkan $\mathrm{pH}$ tanah, dan merubah struktur, kimiawi, dan biologi tanah sehingga penggunaan pupuk anorganik perlu diimbangi dengan pupuk organik (Khairunisa, 2015).

Pupuk organik terdiri dari pupuk organik padat dan cair yang berasal dari material sisa makhluk hidup, limbah tanaman, dan kotoran hewan dan melalui proses pembusukan dalam pembuatannya (Yanto, 2016). Pupuk organik cair merupakan larutan yang mengandung mikroba yang dapat mempercepat pertumbuhan akar, kuncup, bunga, dan pucuk, yang dapat menyediakan unsur hara dan nutrisi bagi tanaman, menjaga kesehatan tanaman, serta meningkatkan kesuburan tanah.

Daya dukung tanah dan efisiensi penyerapan unsur hara akan meningkat apabila diberi mikroba berupa larutan pada tanaman atau tanah secara berkala (Madusari, 2016). Pupuk organik cair mudah larut pada tanah dan mengandung unsur penting yang berguna untuk meningkatkan kesuburan tanah (Slamet $e t$ al., 2005 dalam Kamil, 2016). Pupuk organik dibutuhkan tanaman karena mengandung unsur hara makro dan mikro yang dibutuhkan tanaman dalam pertumbuhan dan produksinya (Afrizon, 2017).

Salah satu pupuk organik cair yang ada di pasaran mengandung unsur hara seperti $\mathrm{N}, \mathrm{P}$, $\mathrm{K}$, C-organik, $\mathrm{Zn}, \mathrm{Cu}, \mathrm{Na}$, unsur mikro, lemak, protein, dan zat pengatur tumbuh yang berfungsi untuk meningkatkan kesuburan tanah, merangsang pertumbuhan tunas baru, serta dapat mengurangi serangan dari hama dan penyakit (Redaksi Agromedia, 2007). Pemberian pupuk organik cair (POC) yang diberikan pada tanaman kelapa kopyor diharapkan dapat merangsang pertumbuhan tanaman karena pada pupuk organik cair (POC) memiliki kandungan unsur N, P, K dan unsur lainnya, sedangkan pemberian pupuk anorganik yang mengandung unsur makro dapat memenuhi kebutuhan unsur hara yang baik bagi tanaman.

\section{Bahan dan Metode}

Penelitian ini dilaksanakan pada bulan Juli 2018 sampai dengan Desember 2018 di lahan Mekarsari, Cileungsi, Bogor dengan ketinggian 
\pm 70 meter diatas permukaan laut dengan jenis tanah Ultisol dan $\mathrm{pH}$ 4,5 - 6. Bahan yang digunakan pada penelitian ini adalah tanaman kelapa kopyor varietas Kelapa Kopyor Genjah Pati umur 13 bulan yang diperoleh dari Asosiasi Petani Kelapa Indonesia (APKI) Desa Sambiroto Kecamatan Tayu Kabupaten Pati Jawa Tengah dengan jarak tanam $8 \mathrm{~m} \times 9 \mathrm{~m}$, pupuk urea, SP36, $\mathrm{KCl}$, air, serta POC NASA®. Alat yang digunakan dalam penelitian ini adalah gelas ukur $100 \mathrm{~mL}$, meteran, alat dokumentasi.

Percobaan ini dilaksanakan menggunakan Rancangan Acak Kelompok (RAK), terdiri dari 16 perlakuan dan masing-masing perlakuan terdiri dari 2 tanaman dan diulang sebanyak 2 kali sehingga diperlukan 64 tanaman. Perlakuan pada percobaan ini merupakan dosis pupuk, sebagai berikut :
A $\quad=100 \%$ pupuk anorganik
$\mathrm{B}=75 \%$ pupuk anorganik $+25 \%$ POC
$\mathrm{C}=50 \%$ pupuk anorganik $+25 \%$ POC
$\mathrm{D}=25 \%$ pupuk anorganik $+25 \%$ POC
$\mathrm{E}=75 \%$ pupuk anorganik $+50 \%$ POC
$\mathrm{F}=50 \%$ pupuk anorganik $+50 \%$ POC
$\mathrm{G}=25 \%$ pupuk anorganik $+50 \%$ POC
$\mathrm{H}=75 \%$ pupuk anorganik $+75 \%$ POC
$\mathrm{I} \quad=50 \%$ pupuk anorganik $+75 \%$ POC
$\mathrm{J}=25 \%$ pupuk anorganik $+75 \%$ POC
$\mathrm{K}=75 \%$ pupuk anorganik $+100 \%$ POC
$\mathrm{L} \quad=50 \%$ pupuk anorganik $+100 \%$ POC
$\mathrm{M}=25 \%$ pupuk anorganik $+100 \%$ POC
$\mathrm{N}=75 \%$ pupuk anorganik $+125 \%$ POC
$\mathrm{O}=50 \%$ pupuk anorganik $+125 \%$ POC
$\mathrm{P}=25 \%$ pupuk anorganik $+125 \%$ POC

Dosis pupuk $100 \%$ untuk pupuk anorganik masing-masing adalah $100 \mathrm{~g}$ urea, $115 \mathrm{~g}$ SP36, serta $150 \mathrm{~g} \mathrm{KCl}$ per pohon. Dosis pupuk 100\% untuk POC adalah $60 \mathrm{~mL}$ per pohon yang dilarutkan dalam air menjadi 1 L (konsentrasi $6 \%)$.

Parameter yang diamati dalam percobaan ini yaitu: pertambahan tinggi tanaman, pertambahan lilit batang, jumlah daun, dan luas daun. Analisis yang digunakan yaitu analisis keragaman (ANOVA) pada taraf nyata 5\%. Bila terdapat hasil uji yang berbeda nyata maka akan diuji lanjut menggunakan uji Scott-Knott dengan taraf nyata $5 \%$.

\section{Hasil dan Pembahasan}

Pertambahan tinggi tanaman. Hasil pengamatan pertambahan tinggi tanaman pada 12 dan
24 minggu setelah perlakuan (MSP) dapat dilihat pada Gambar 1. Berdasarkan analisis uji $\mathrm{F}$ pada taraf nyata 5\%, semua perlakuan pemberian pupuk anorganik yang dikombinasikan dengan POC tidak berbeda nyata terhadap pertambahan tinggi tanaman kelapa kopyor TBM. Hal ini menunjukkan bahwa pengaruh pemberian perlakuan sama antara tanaman yang diberi pupuk anorganik saja dengan tanaman yang diberi kombinasi pupuk anorganik dengan POC. Pemberian dosis $50 \%$ pupuk anorganik ditambah 25\% pupuk organik cair cenderung memberikan tinggi lebih baik. Penggunaan pupuk anorganik secara terus-menerus dan tidak diimbangi dengan penggunaan pupuk organik dapat menyebabkan penurunan pada sifat fisik tanah seperti struktur tanah, kapasitas tukar kation (KTK) dan biologi tanah (Marsono dan Sigit, 2001).

Balai Penelitian Bioteknologi Perkebunan (1998) menyatakan bahwa penggunaan pupuk organik dimaksudkan bukan untuk menggantikan penggunaan pupuk anorganik seluruhnya melainkan untuk meningkatkan serapan hara dari pupuk anorganik. Menurut Rikamonika (2012), fungsi utama POC adalah memberikan nutrisi bagi tanaman dan juga tanah, nutrisi yang terkandung pada POC berupa unsur hara makro dan mikro yang mampu meningkatkan pertumbuhan dan produksi tanaman.

Ketersediaan hara pada perlakuan C (50\% pupuk anorganik $+25 \%$ POC) cenderung menghasilkan pertambahan tinggi tanaman yang baik dibandingkan dengan perlakuan lainnya, hal ini diduga karena hara yang tersedia di dalam kombinasi pupuk anorganik dan POC dapat sepenuhnya dimanfaatkan tanaman kelapa dalam proses pertumbuhannya. Penambahan POC juga dapat memperbaiki sifat fisik, kimia, dan biologi tanah serta mampu menyediakan senyawa karbon yang dapat menunjang pertumbuhan tanaman (Setyorini et al., 2006).

Pupuk organik cair selain mengandung unsur hara makro dan mikro, juga terkandung zat pengatur tumbuh (ZPT) seperti auksin, giberelin, dan sitokinin dimana ZPT ini tidak terkandung dalam pupuk anorganik. Zat pengatur tumbuh ini membantu penyerapan unsur hara untuk menunjang pertumbuhan tanaman. Hal ini sesuai dengan pernyataan Pangaribuan et al. (2017) yang menyatakan 
bahwa kandungan hormon auksin dan giberelin dalam POC dapat meningkatkan kemampuan dan keefektifan tanaman dalam menyerap nutrisi. Kelebihan POC jika dibandingkan dengan pupuk anorganik salah satunya yaitu penyerapan hara berjalan lebih cepat karena hara yang terkandung dalam POC sudah dalam keadaan terlarut (Hadisuwito, 2007).

Pertambahan lilit batang. Pemberian pupuk anorganik yang dikombinasikan dengan POC menurut analisis uji F pada taraf nyata 5\% tidak memberikan pengaruh yang berbeda nyata terhadap pertambahan lilit batang (Gambar 2). Hal ini menunjukan bahwa adanya pengaruh yang sama antara tanaman yang diberi pupuk anorganik saja dengan yang diberi kombinasi pupuk anorganik dengan POC. Pangaribuan et al. (2017) menyatakan bahwa penggunaan pupuk anorganik secara berlebihan akan berdampak terhadap penurunan kualitas tanah sehingga penggunaannya perlu diimbangi dengan pupuk organik. Penggunaan pupuk organik juga dapat memperbaiki kesehatan tanah yang telah rusak karena penggunaan pupuk anorganik secara terus menerus (Ariyanti et al., 2017)

Pertambahan lilit batang pada tanaman kelapa kopyor TBM yang diberi POC cenderung memberikan respons yang baik jika dibandingkan dengan tanaman yang tidak diberi POC, hal ini karena pupuk organik dalam bentuk cair dapat meningkatkan suplai unsur hara pada tanaman dibandingkan pupuk anorganik (Lingga, 1999). Unsur hara yang terkandung dalam POC juga lebih lengkap dibandingkan dengan pupuk anorganik. POC mengandung unsur hara makro, mikro, asam organik, dan hormon yang dibutuhkan tanaman (Sarwono, 2011 dalam Adiatma, 2016).

Kandungan unsur hara perlakuan I (50\% pupuk anorganik $+75 \%$ POC) pada 12 MSP cenderung optimal dalam meningkatkan pertambahan lilit batang, akan tetapi pada 24 MSP pemberian POC dapat dikurangi dosisnya sebanyak $25 \%$ - 50\% sesuai dengan perlakuan C (50\% pupuk anorganik $+25 \%$ POC) dan F (50\% pupuk anorganik $+50 \%$ POC) yang menghasilkan pertambahan lilit batang cenderung baik. Hal ini sejalan dengan penelitian Suwarno (2013), yang menyatakan bahwa tanaman akan tumbuh subur apabila unsur hara yang dibutuhkan tanaman tersedia dalam proporsi yang seimbang, terutama unsur hara makro seperti N, P, dan K. Kandungan unsur hara $\mathrm{N}, \mathrm{P}$, dan $\mathrm{K}$ yang terkandung dalam POC dapat terserap optimal oleh tanaman kelapa kopyor TBM dengan dosis 25\% - 75\% untuk meningkatkan pertambahan lilit batang.

Jumlah daun. Berdasarkan hasil uji analisis statistik, pemberian pupuk anorganik yang dikombinasikan dengan POC tidak berpengaruh terhadap jumlah daun kelapa kopyor TBM pada 12 MSP akan tetapi berbeda nyata pada 24 MSP menurut uji lanjut ScottKnott pada taraf nyata 5\% (Gambar 3). Unsur hara yang terkandung pada kombinasi pupuk anorganik dengan POC pada perlakuan C (50\% pupuk anorganik $+25 \% \mathrm{POC}$ ) dapat memenuhi kebutuhan hara tanaman masing-masing pada 24 MSP dan salah satu unsur hara yang menunjang pertumbuhan daun yaitu nitrogen. Novrian (2005) menyatakan bahwa unsur $\mathrm{N}$ dibutuhkan tanaman dalam jumlah yang relatif besar pada setiap pertumbuhannya, terutama pertumbuhan vegetatif tanaman. Unsur nitrogen juga membantu dalam proses pembelahan dan pembesaran sel yang menyebabkan daun muda lebih cepat untuk berubah menjadi daun sempurna. Selain disebabkan oleh ketersediaan unsur hara nitrogen, unsur fosfor juga berpengaruh dalam proses pembentukan daun (Haryadi et al., 2015).

Kandungan unsur hara pada POC selain $\mathrm{N}$, $\mathrm{P}$, dan $\mathrm{K}$ juga mengandung ZPT seperti auksin, sitokinin, dan giberelin. Hormon sitokinin di dalamnya mengandung nitrogen yang berperan dalam proses sintesis asam amino dan protein. Asam amino dan protein dimanfaatkan dalam pertumbuhan daun (Gardner, 1991 dalam Saefas et al., 2017). Berdasarkan Gambar 5, rata-rata pertambahan jumlah daun tanaman kelapa kopyor TBM berkisar antara $0,77 \mathrm{~cm}^{2}-1,33 \mathrm{~cm}^{2}$ perbulan. Menurut Lakitan (1993), faktor genetik menentukan jumlah daun yang akan terbentuk pada tanaman. 


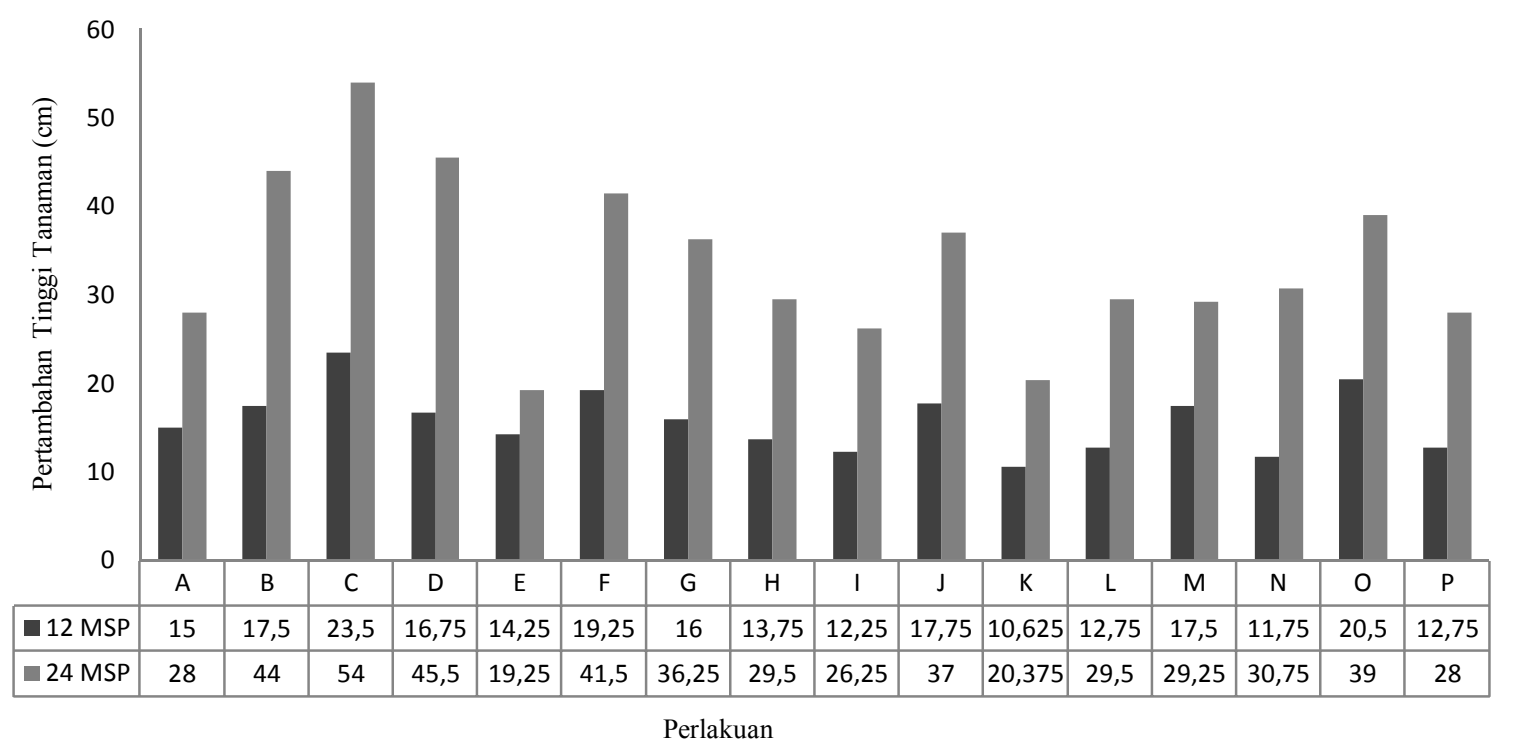

Gambar 1. Diagram pertambahan tinggi tanaman kelapa kopyor TBM dengan pemberian pupuk anorganik yang dikombinasikan dengan POC.

Keterangan : Angka-angka pada diagram tidak berbeda nyata berdasarkan uji F pada taraf 5\%

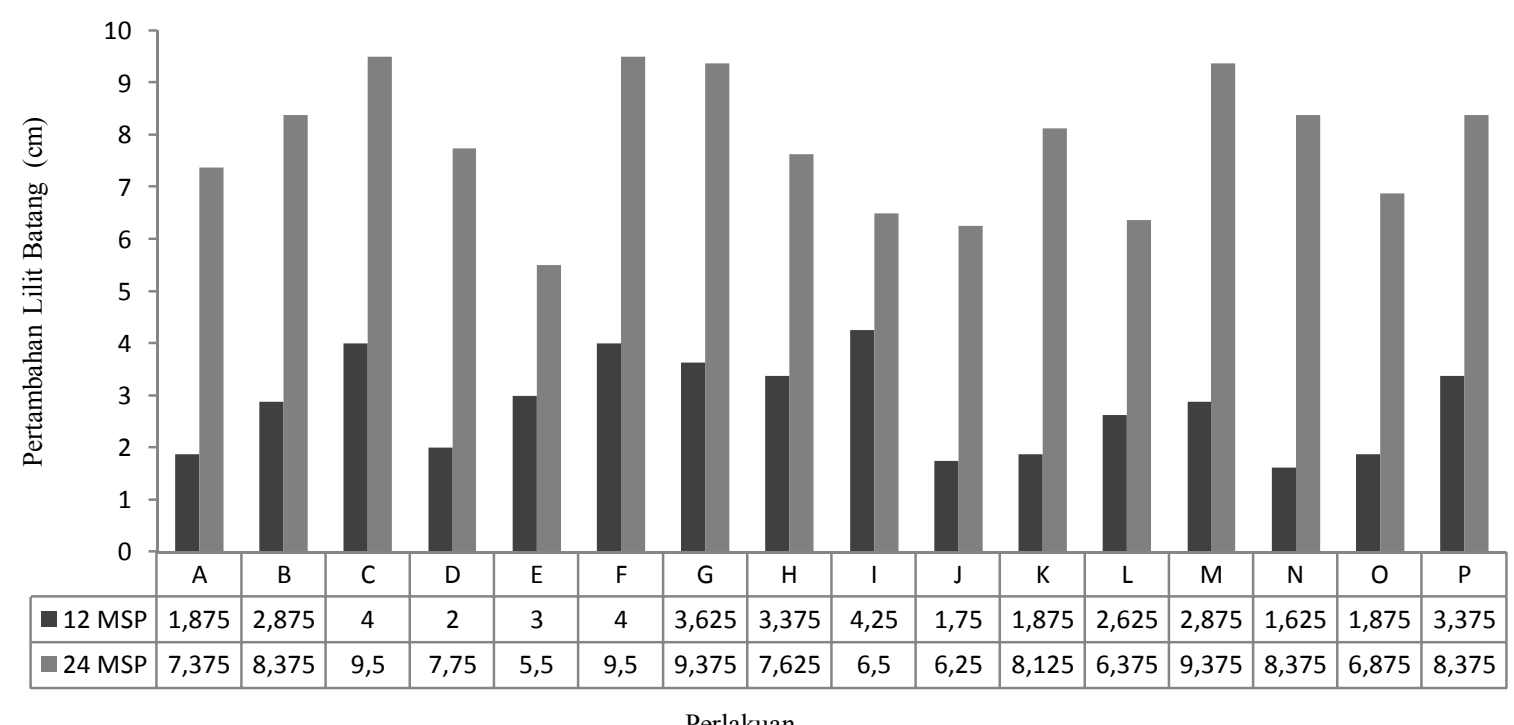

Gambar 2. Diagram pertambahan lilit batang tanaman kelapa TBM dengan pemberian pupuk anorganik yang dikombinasikan dengan POC

Keterangan : Angka-angka pada baris yang sama di bawah diagram yang tidak diikuti huruf menunjukkan tidak berbeda nyata menurut uji lanjut Scott-Knott pada taraf nyata $5 \%$. 


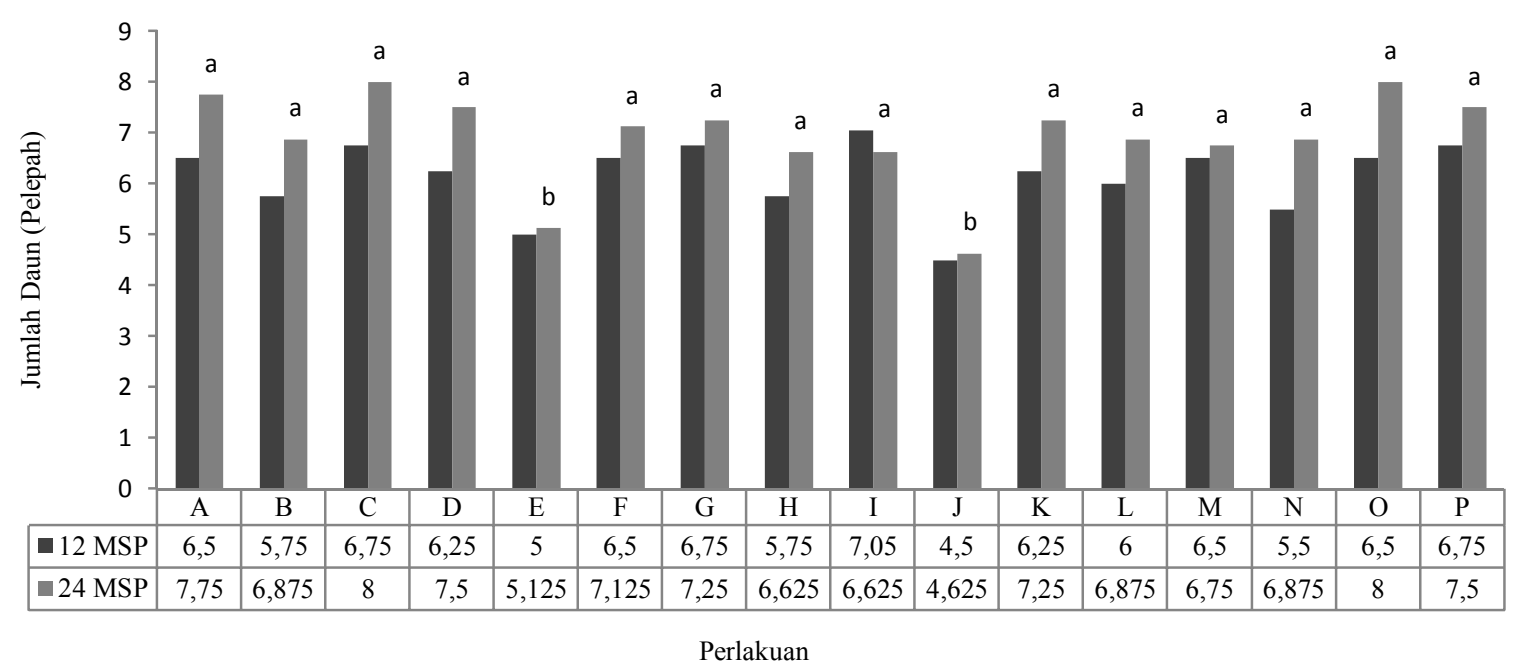

Gambar 3. Diagram jumlah daun tanaman kelapa kopyor TBM dengan pemberian pupuk anorganik yang dikombinasikan dengan POC.

Keterangan : Angka-angka pada baris yang sama di bawah diagram yang tidak diikuti huruf menunjukkan tidak berbeda nyata menurut uji lanjut Scott-Knott pada taraf nyata $5 \%$.

Tabel 1. Rata-rata luas daun tanaman kelapa kopyor TBM dengan pemberian pupuk anorganik yang dikombinasikan dengan POC.

\begin{tabular}{cc}
\hline \multirow{2}{*}{ Perlakuan } & $\begin{array}{c}\text { Rata-rata luas daun tanaman } \\
\left(\mathrm{cm}^{2}\right)\end{array}$ \\
\cline { 2 - 2 } & $24 \mathrm{MSP}$ \\
\hline A & $606.45 \mathrm{~b}$ \\
B & $669.56 \mathrm{~b}$ \\
C & $637.23 \mathrm{~b}$ \\
D & $502.23 \mathrm{~b}$ \\
E & $1215.28 \mathrm{a}$ \\
F & $811.50 \mathrm{~b}$ \\
G & $979.06 \mathrm{a}$ \\
H & $1267.97 \mathrm{a}$ \\
I & $640.50 \mathrm{~b}$ \\
J & $384.78 \mathrm{~b}$ \\
K & $1110.16 \mathrm{a}$ \\
L & $798.73 \mathrm{~b}$ \\
M & $1109.00 \mathrm{a}$ \\
N & $1771.94 \mathrm{a}$ \\
O & $745.67 \mathrm{~b}$ \\
P & $1002.22 \mathrm{a}$ \\
\hline
\end{tabular}

Keterangan : Diagram yang diikuti huruf yang sama maka tidak berbeda nyata menurut uji lanjut Scott Knott taraf nyata 5\%

Luas daun: Luas daun pada tanaman kelapa kopyor belum menghasilkan (TBM) menurut uji beda nyata Scott-Knott pada taraf nyata 5\% (Tabel 1) berbeda nyata pada 24 MSP dengan adanya pemberian pupuk anorganik yang dikombinasikan dengan POC.
Hal ini sejalan dengan pernyataan Jumin (2001) bahwa fungsi unsur hara nitrogen adalah meningkatkan pertumbuhan vegetatif tanaman terutama pertumbuhan daun, konsentrasi nitrogen yang tinggi menghasilkan total luas daun yang lebih besar. Unsur hara yang menunjang pertambahan rata-rata luas daun selain nitrogen yaitu fosfor. Menurut Syarif (1985 dalam Thuti 2017) menyatakan bahwa unsur $P$ digunakan dalam perkembangan jaringan meristem. Berkembangnya jaringan meristem menyebabkan sel-sel akan memanjang dan membesar, sehingga bagian tanaman seperti daun dan pucuk akan semakin panjang dan lebar serta akan mempengaruhi luas daun tanaman.

\section{Kesimpulan}

Dosis kombinasi pupuk anorganik dan POC yang menghasilkan respons yang baik adalah $50 \%$ pupuk anorganik $+25 \%$ POC karena mampu memberikan pertumbuhan yang cenderung lebih baik hampir pada setiap parameter, sementara $75 \%$ pupuk anorganik + $125 \%$ POC pada parameter luas daun.

\section{Ucapan Terima Kasih}

Penulis ucapkan terimakasih kepada seluruh staff PT. Mekar Unggul Sari yang telah membantu penulis dalam penelitian ini. 


\section{Daftar Pustaka}

Adiatma, R. N. 2016. Karaktersitik dan analisis keuntungan pupuk organik cair biourine sapi bali yang diproduksi menggunakan mikroorganisme lokal (MOL) dan lama fermentasi yang berbeda. Skripsi. Fakultas Peternakan. Universitas Hasanuddin Makassar.

Afrizon. 2017. Pertumbuhan bibit kelapa sawit (Elaeis guineensis jacq.) dengan pemberian pupuk organik dan anorganik. Jurnal Agritepa. Vol 3 (2).

Ariyanti. M., M. A. Soleh., Y. Maxiselly. 2017. Respon pertumbuhan tanaman aren (Arenga pinnata merr.) dengan pemberian pupuk organik dan pupuk anorganik berbeda dosis. Jurnal Kultivasi. 16(1). Hal 271-278

Balai Penelitian Bioteknologi Perkebunan. 1998. Penemuan Teknis Bioteknologi Perkebunan untuk Praktek Pemberdayaan Bioteknologi Perkebunan untuk Peningkatan Efisiensi Usaha Perkebunan. Balai Penelitian Bioteknologi Perkebunan. Bogor. 71 hal

Bursatianyo. 2015. Populasi Unggul Kelapa Genjah Kopyor. http://perkebunan. litbang.pertanian.go.id/?p=7623. Diaksespada 3 Januari 2018.

Hadisuwito, S. 2007. Membuat Pupuk Kompos Cair. PT Agromedia Pustaka. Jakarta.

Hariokusumo, B. 2016. Pengaruh pemupukan terhadap pengembangan dan produksi buah kelapa kopyor (Cocos nucifera L.). Skripsi. Institut Pertanian Bogor. Bogor.

Haryadi, D, H.,Yeti, S., Yoseva. 2015. Pengaruh pemberian beberapa jenis pupuk terhadap pertumbuhan dan produksi tanaman kailan (Brassica alboglabra 1.). Jom Faperta. Vol 2. No 3.

Jumin, H, B. 2001. Dasar-Dasar Agronomi. Rajawali. Jakarta

Kamil, M, F. 2016. Analisis kandungan unsur hara pada pembuatan mol bonggol pisang dengan penambahan ampas tahu (Bagasse). Skripsi. Politeknik Pertanian Negeri Samarinda. Samarinda.

Khairunisa. 2015. Pengaruh pemberian pupuk organik, anorganik, dn kombinasinya terhadap pertumbuhan dan hasil sawi hijau (Brassica juncea L. Var. Kumala). Skripsi. Universitas Islam Negeri Maulana Malik Ibrahim. Malang
Lakitan, B. 1993. Dasar-dasar Fisiologi Tumbuhan. Raja Grafindo Persada. Jakarta

Lingga, P. 1999. Petunjuk Penggunaan Pupuk. Penebar Swadaya. Jakarta.

Madusari, S. 2016. Kajian aplikasi mikroorganisme lokal bonggol pisang dan mikoriza pada media tanam terhadap parakter pertumbuhan bibit kepala sawit (Elaeis guineensis Jacq.). Jurnal Citra Widya Edukasi Vol.VIII No.1. Hal : 2.

Marsono dan P. Sigit. 2001. PupukAkar, Jenis dan Aplikasi.Penebar Swadaya, Jakarta.

Novrian. 2005. Petunjuk Pemupukan Efektif. Agromedia Pustaka. Depok. Hal 15-35

Pangaribuan. D. H., K. Hendarto, K. Prihartini. 2017. Pengaruh pemberian kombinasi pupuk anorganik tunggal dan pupuk hayati terhadap pertumbuhan dan produksi tanaman jagung manis (zea mays saccharata sturt) serta populasi mikroba tanah. Jurnal Floratek. 12(1). 1-9

Redaksi Agromedia. 2007. Petunjuk Pemupukan. Agromedia Pustaka. Jakarta.

Rikamonika. 2012. Respon tanaman kelapa sawit terhadap pupuk fosfat alam berkualitas tinggi untuk mendorong peningkatan produksi tanaman perkebunan. Skripsi Jurusan Agroteknologi. Fakultas Pertanian. Universitas Sumatera Utara. Medan.

Saefas. S. A., Rosniawati, S., Maxiselly, Y. 2017. Pengaruh konsentrasi zat pengatur tumbuh alami dan sintetik terhadap pertumbuhan tanaman the (Camellaia sinensis L.) O. Kuntze) klon GMB 7 setelah centering.Jurnal Kultivas. 16(2).

Setyorini. D., R. Saraswati., E.K. Anwar. 2006. Kompos. Resume buku pupuk hayati pupuk organik. Tersedia: balittanah. litbang.pertanian.go.id.

Suwarno, V. S. 2013.Respon pertumbuhan dan produksi tanaman mentimun (Cucumis sativus L.) melalui perlakuan pupuk NPK pelangi. Jurnal Karya Ilmiah Mahasiswa Universitas Negeri Gorontalo. 1(1): 1-12.

Thuti., A. I.Amri., Islan. 2017. Pengaruh pemberian beberapa jenis pupuk majemuk pada berbagai jenis tanah terhadap pertumbuhan bibit kelapa sawit (Elaeis guineensis Jacq.) di pre-nursery. Jom Faperta. 4(1).

Yanto, K. 2016. Pemberian pupuk organik cair terhadap pertumbuhan bibit kelapa sawit (Elaeis guineensis Jacq.) pada Pembibitan Utama JOM FapertaVol : 3 No : 2 